\title{
Alain Borne, Poeta al suo tavolo
}

\section{Damiano Sinfonico}

\section{(2) OpenEdition}

\section{Journals}

\section{Edizione digitale}

URL: http://journals.openedition.org/studifrancesi/3847

DOI: 10.4000/studifrancesi.3847

ISSN: 2421-5856

\section{Editore}

Rosenberg \& Sellier

\section{Edizione cartacea}

Data di pubblicazione: 1 décembre 2012

Paginazione: 608

ISSN: 0039-2944

\section{Notizia bibliografica digitale}

Damiano Sinfonico, «Alain Borne, Poeta al suo tavolo», Studi Francesi [Online], 168 (LVI | III) | 2012, online dal 30 novembre 2015, consultato il 05 mars 2021. URL: http://journals.openedition.org/studifrancesi/ 3847 ; DOI: https://doi.org/10.4000/studifrancesi.3847

Questo documento è stato generato automaticamente il 5 mars 2021.

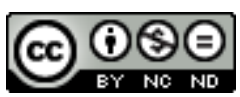

Studi Francesi è distribuita con Licenza Creative Commons Attribuzione - Non commerciale - Non opere derivate 4.0 Internazionale. 


\title{
Alain Borne, Poeta al suo tavolo
}

\author{
Damiano Sinfonico
}

\section{NOTIZIA}

ALAIN BORNE, Poeta al suo tavolo, traduzione e cura di Lucetta FRISA, Novi Ligure, Joker, 2011, pp. 109.

1 La poesia di Alain Borne viene per la prima volta presentata al pubblico italiano con una piccola antologia edita da Joker. Protagonista di questa iniziativa, Lucetta Frisa ha scelto e tradotto i testi, fornendo un ampio spettro della variegata produzione letteraria di Borne, dalle prose liriche alle poesie attraversate da una linea tragica a quelle attraversate da un amore intenso per un essere che forse appartiene solo al mondo del sogno. La traduzione permette di accedere alla densità delle immagini e al ritmo del verso che ritroviamo nel testo originale. La diretta significazione del testo, la cristallina emergenza delle immagini al di sopra della pagina, si ricompone con precisa cura nel testo tradotto, che diventa tramite e traghetto di un dire poetico intensamente radicato nella sua dimensione di canto. 